\title{
Examining the opportunities and challenges of the Kra Canal: a PESTELE/SWOT analysis
}

\author{
Po-Hsing Tseng \\ Department of Shipping and Transportation Management, \\ National Taiwan Ocean University, Keelung, Taiwan, and \\ Nick Pilcher \\ The Business School, Edinburgh Napier University, Edinburgh, UK
}

Examining the Kra Canal

Received 20 February 2021 Revised 8 June 2021 Accepted 20 July 2021

\begin{abstract}
Purpose - Much literature considers future impacts of the Kra Canal on shipping times and on individual countries. In this paper, the authors consider the maritime business potential of the Kra Canal for companies, ports and countries.

Design/methodology/approach - Based on a combination of a review of the extant literature, quantitative data from relevant calculations and qualitative data from semi-structured interviews with experts $(n=20)$ from four countries in the region, this paper contextualises the business potential of the Kra Canal through a PESTELE (political, economic, social, technological, environmental, legal and ethical) analysis before outlining a more targeted SWOT (strengths weaknesses, opportunities and threats) analysis to consider the potential for maritime business.

Findings - The PESTELE analysis reveals that there are a number of challenges related to the construction and possibility of the Kra Canal being built such as its impact on the political balance within the Association of South East Asian Nations (ASEAN) region. The SWOT analysis shows that the potential of the Kra Canal for maritime business is significant, and that the strengths and opportunities of increased route possibilities and reduced sailing times outweigh any weaknesses and threats.

Originality/value - Most studies into the Kra Canal focus on highly specific research targets or provide a particular perspective (e.g. historical). This paper, by drawing on two commonly used analytical frameworks, considers the canal for the first time from a wider context perspective as well as a specifically business one. Recommendations are made for policy makers and maritime businesses on the basis of the results.
\end{abstract}

Keywords Kra Canal, Shipping, PESTELE, SWOT

Paper type Research paper

\section{Introduction}

The Kra Canal (also called the Carat Canal) in Thailand [1] has long been considered to offer important potential benefits for maritime business, particularly for reducing shipping times, something which could integrate well with China's recent Belt and Road Initiative and the Maritime Silk Route (Zeng et al., 2018). The canal could reduce shipping distances and times (it might reduce $1,200 \mathrm{~km}$ or about $27 \mathrm{~h}$ of sailing time) and increase shipping capacity (Rahman et al., 2016) between the East Asia-Middle East area, bypassing Singapore Port and the congested Malacca Straits (Lau and Lee, 2016). From a business perspective, the Kra Canal presents opportunities for significant regional port development in many Asian countries (e.g. Thailand, Vietnam and China) and allows for greater economies and increased competitiveness in goods prices. Concomitantly, these also provide business advantages through enhanced corporate social responsibility (CSR) as an effect of positive environmental and network scheduling (Sulong, 2012; Rahman et al., 2016; Heng and Yip, 2018).

\footnotetext{
(C) Pacific Star Group Education Foundation. Licensed re-use rights only.
}

This research was partially supported by Ministry of Science and Technology, Taiwan (Project number MOST 110-2410-H-019-018).

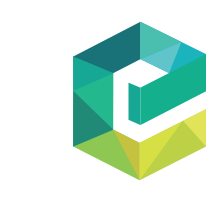

Maritime Business Review Vol. 7 No. 2, 2022 pp. 161-174

Emerald Publishing Limited 2397-3757 
MABR

7,2

162

In addition, from China's perspective of China, as the canal would be part of the Maritime Silk Road of "One Belt One Road", it would impact on maritime business in China and those doing business with China.

Indeed, the new canal's impact on maritime business can be compared to other potential new routes, for example, the Northern Sea Route (NSR) (see Zeng et al., 2018). Yuan et al. (2020) used the Arctic Sea Route and the Kra Canal to explore their impacts on the operational resilience of container lines and found both would positively impact maritime business. In this context, many studies indicate NSR (when sailing along the coast of Russia) can potentially reduce nautical miles of shipping distance between Rotterdam and Shanghai ports by $40 \%$ compared to the traditional Suez Canal route (Meng et al., 2017; Aksenov et al., 2018). In general, new routes attract shipping companies to deploy fleets and rethink port choices if they can lower operation costs (e.g. labour cost, fuel cost, etc.) and thereby enhance economic sustainability.

The Kra Canal can also be compared to canals such as the Nicaragua anal (Chen et al., 2019) or the Panama Canal in its impact on business, and some have described it as the “oriental Panama Canal" (Zeng et al., 2018). Mulligan and Lombardo (2011) found the Panama Canal's impact to positively affect business by reducing overland traffic and sailing times. Lin and Huang (2018) also found the Panama Canal expansion will have an even greater positive impact on business. Zeng et al. (2018) further note how the Kra Canal will positively impact business due to the evolution of hub ports under China's Belt and Road Initiative.

However, despite all the potential the canal affords for maritime business, and although it has been talked about since the fifteenth century, through to Japanese interest in the 1980s and the more recent interest from China (Sulong, 2012), nothing has been built. Moreover, in September 2020, it was even mooted in Thailand that the government is considering a rail link rather than a canal (Maritime Executive, 2020).

In order to provide a thorough review of issues involved with building the Kra Canal for governments, shipping companies and investors, this paper undertakes two analyses: a PESTELE (political, economic, social, technological, environmental, legal and ethical) analysis and a SWOT (strengths, weaknesses, opportunities and threats) analysis. Both these analyses draw on quantitative data in the form of calculations for illustration of particular scenarios (such as the impact of reduced sailing distances on emissions) and on qualitative data from semi-structured interviews with shipping experts in government and the private sector for shipping companies as engineers, captains and managers. The experts interviewed were from two Association of South East Asian Nations (ASEAN) countries (Thailand $(n=5)$ and Singapore $(n=5))$ and two areas where trade would go through the Kra Canal (China $(n=5)$ and Taiwan $(n=5))[2]$.

PESTEL analyses are much used in the business and marketing literature and have also been used in relation to the impact of the Kra Canal on Malaysia (Rahman et al., 2016). The PESTELE analysis here does not focus on any specific country but on the canal in a wider regional and global perspective, aiming to provide a wider background and contextualisation of issues involved with building (or not building) the Kra Canal in order to help governments and companies consider the likelihood of the canal's construction. Given the lengthy time it takes to develop ports and new routes, such knowledge is argued to be highly useful for businesses. The SWOT analysis, by comparison, is more specifically targeted towards maritime businesses and considers the canal from the perspectives of port authorities and shipping companies The SWOT analysis also provides information for those considering any decision to attempt to build the canal and also provides potential arguments for lobbying and leverage with regard to eliciting funding and investment for the canal from countries outside Thailand. In other words, if a SWOT analysis shows significant benefits from the Kra Canal for businesses in China, such information could be used in arguments by the Thai Government for the building of the canal to be a multi-national venture. As far as the 
authors are aware, such a consideration of the Kra Canal from this wider PESTELE and simultaneous more specific SWOT analysis has not been undertaken before, and complements the literature by identifying factors for consideration by maritime businesses such as ports and shipping companies, as well as by larger bodies such as governments and international bodies. The remainder of the paper is organised as follows. Sections 2 and 3 review the related literature. Section 2 presents the development background of the Kra Canal, and Section 3 reviews maritime business-related Kra Canal studies. The PESTELE and SWOT analyses are illustrated in Section 4. Finally, key points and considerations for ports and shipping companies are provided in the conclusion.

\section{The development background of Kra Canal in Thailand}

The Kra Canal was first presented in Siam (Thailand) in 1677 (Min, 2015; Rahman et al., 2016). It was vaunted as an important potential passage way to connect the Indian Ocean, the Andaman Sea and the Gulf of Siam in Thailand. Much later, in the 1980s, Larouche and the Mitsubishi Research Institute conceptualised a sea-level canal across the Kra Peninsula (Sulong, 2012), but this never materialised, possibly for political reasons (Sulong, 2012). Then, in the late 1990s, Thailand's authorities fully supported building the canal, arguing it might bring much needed positive economic effects after the Asian financial crisis (Sulong, 2012) of 1997-1998. Regarding practicalities, in 1999, Japan's Global Infrastructure Fund estimated that a $50 \mathrm{~km}$ long Kra Canal would cost at least 20-28bn USD (Thongsin, 2002; Billington, 2011; Rahman et al., 2016), and the canal was not built at this time. In the 2000s, the Kra Canal project failed again, this time due to internal political conflicts in Thailand, with Prime Minister Thaksin Shinawat's Government overthrown through a military coup (Sulong, 2012).

Notably, the Kra Canal is a huge-scale infrastructure project. The proposal is that it will be approximately $102 \mathrm{~km}$ long (in contrast to the Japanese estimate of $50 \mathrm{~km}$ from the 1980s), 400 metres wide and 25 metres in depth, and sufficiently large enough to allow for any cargo vessel type, including ultra large crude carriers with a 300,000 deadweight tonnage (Rahman et al., 2016; Heng and Yip, 2018). Yet, despite such challenges, the potential benefits are huge. For example, it is estimated that the canal can shorten shipping times by two to three days compared to the Malacca Straits route (Lam, 2018). Such benefits bring savings in time, crew costs, fuel consumption and emissions reductions, thereby enhancing CSR. Also, the Kra Canal can avoid threat of pirates, congestion and potential accidents in the Strait of Malacca [3] (see Figure 1) (Heng and Yip, 2018), meaning safer and more secure passages for goods, reduced insurance costs and safer passages for personnel. The canal also has the potential for the development and evolution of any feeder or hub ports, and for those servicing the canal in Thailand.

To date, however, the Kra Canal project has not materialised, according to the literature due to uncertainties, related to a lack of funds, technological capability, indecisive political leadership and geo-political issues (Lau and Lee, 2016). Indeed, even though China and Thailand have planned to cooperate on this project (Sulong, 2012; Heng and Yip, 2018), recently, the Thai Government has still not committed and is now considering a rail link instead (Maritime Executive, 2020) [4]. In this context of potential and indecision and failure to start building the canal, it is important to note that it was still the case that the potential positive effects of the Kra Canal for business came to be emphasised again by neighbouring countries (e.g. Thailand, Taiwan and nearby countries or trade partners (e.g. some of those in the ASEAN)) and shipping companies, port authorities and international investors since many of these countries' could benefit from the reduced shipping times, cost-savings and enhanced safety through avoidance of piracy focused waters (Rahman et al., 2016). Also, the environmental benefits and enhanced CSR in reduction of emissions would also be tangible (Rahman et al., 2016).

Nevertheless, and despite the benefits or reduced journey times, there may be disadvantages for shipping companies and for some ASEAN countries. For example, although the Kra Canal can 


\section{MABR \\ 7,2}

164

Figure 1.

The location of Kra Canal

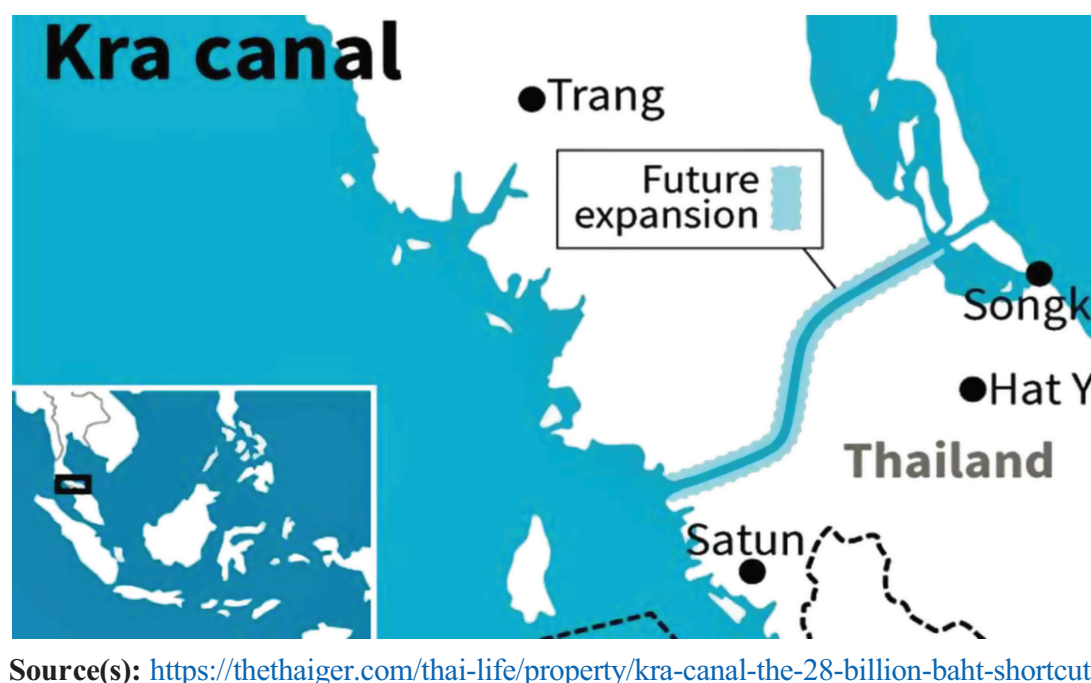

offer an alternative route in lieu of the congested Strait of Malacca and reduce sailing distances, large containerships may not obtain economic benefits since they must cease calling at important Southeast Asian ports (e.g. Singapore and Klang) (Figure 2).

Figure 2.

New route of Kra (Carat) Canal

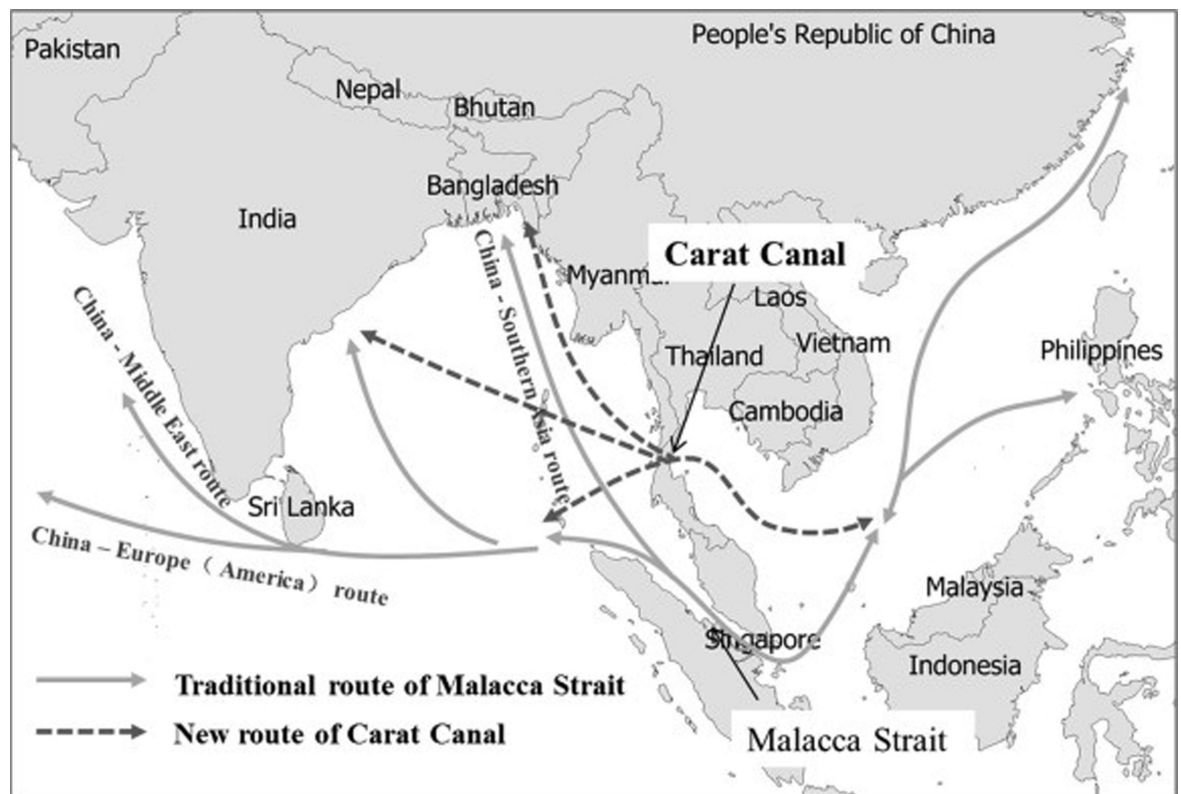

Source(s): Zeng et al. (2018) 
For the Thai authorities, the Kra Canal offers the potential to provide business benefits from tolls, port facilities charges and development of the surrounding area, although such benefits for the Thai authorities represent a potential disadvantage for other businesses if they must pay a toll (see SWOT analysis below). However, the Thai Government has faced many problems related to financial, political and economic relationships, technical and environmental issues (Lam, 2018). Financially, although the World Bank, Asian Development Bank or Chinese companies potentially have interests to provide funding for the canal, these remain unconfirmed (Lau and Lee, 2016). Second, political instability and violence issues over many years have discouraged foreign investors, making them nervous regarding the Thai Government's ability to provide a safe investment and operational environment. Third, engineering challenges exist for the construction of the canal. Some American scientists have even suggested the use of nuclear explosives to ease construction and save up to $40 \%$ of the costs (Lau and Lee, 2016), although this would have potentially serious and adverse environmental impacts, and also issues related to health and safety during the construction of the canal. Finally, despite its potentially positive impacts in reducing emissions and shipping journey times (Rahman et al., 2016), the ecological impacts of this canal will also bring negative environmental externalities both during its construction and on the environment it is constructed in. Construction explosions might bring ground shock, air blast, dust cloud and air pollution, and the natural environment it traverses will be irreversibly altered.

In addition, some stand to potentially lose business from the development of the Kra Canal, certainly in the short to medium term. For example, Singapore Port's business will potentially be significantly affected if the Kra Canal is constructed and shipping companies switch routes along the Europe-Asia route. Taking Yang Ming container shipping company (Far East-Europe Loop 2) as an example, the route is rotated as Qingdao - Pusan - Shanghai - Ningbo - Yantian Singapore - Rotterdam - Le Havre-Hamburg - Rotterdam-Suez/EL Sweis-Qingdao (Figure 3).

If Singapore is bypassed using the Kra Canal, the route will be rotated as Qingdao - Pusan -Shanghai-Ningbo - Yantian - Kra Canal - Rotterdam - Le Havre-Hamburg - Rotterdam Suez/EL Sweis-Qingdao. Since the sailing distance and time is reduced, the ship utilisation can be increased during the port rotation. Whilst representing significant and positive business gains for Yang Ming Marine Corp, this represents significant negative business impact for Singapore, and this in turn could impact upon the wider safety of the region if the canal leads to division in the region.

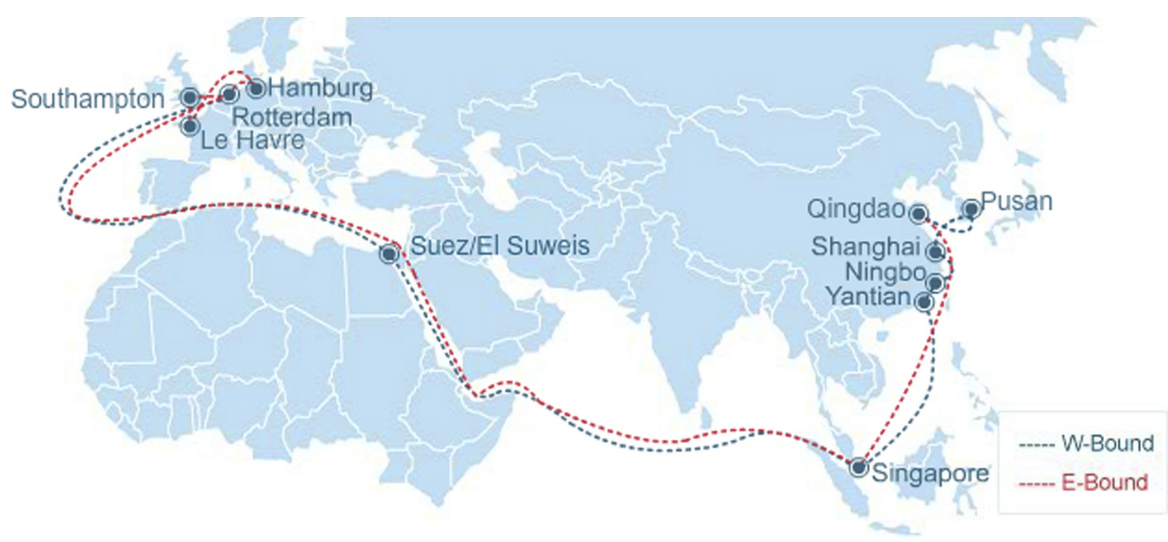

Source(s): Yang Ming Marine Corp. https://www.yangming.com/

\section{Examining the Kra Canal}

Figure 3. Shipping routes in Far East-Europe Loop 2 
MABR

7,2

166

\section{Past studies of Kra Canal or similar issues}

Past scholars have adopted a variety of approaches to study a variety of aspects related to the Kra Canal, many with a direct relevance for maritime business, and others with indirect relevance. With regard to the impact of the canal on different countries in the Association of South East Asian Nations (ASEAN [5]). For example, Rahman et al. (2016) used a PESTEL analysis to focus on the Kra Canal's potential impact on maritime business patterns on Malaysia. In other work, Sulong (2012) used a literature-based analytical approach to consider the impact of the canal on the ASEAN nations as a whole and individual nations such as Singapore or Thailand. In another analytical piece, Er (2018) explored the relationship and policy implications of the Kra Canal and China's Maritime Silk Road, specifically considering relations between Thailand and China. Whilst concluding the canal has not yet materialised due to internal Thai political struggles, Er (2018) also concludes that the canal could be a geo-political and economic "game-changer" for the region.

Another focus of study has been predictive, commonly drawing on quantitative and mathematical modelling techniques to assess and forecast the impact of the canal on specific aspects of shipping. For example, Heng and Yip (2018) described the situation of the Kra Canal and analysed its impacts on the tanker market, in which willingness to pay and the differential-pricing policy were presented and discussed. From a business perspective, they identified that the Kra Canal would benefit business in times when the tanker market was volatile. In other work, Zeng et al. (2018) used a modified gravity prediction model with entropy maximising principle to analyse the potential impact of the canal on key hub ports for the new routes, finding the canal would have a significant and positive impact on the growth and evolution of hub parts. Similarly, Yuan et al. (2020) used a semi-quantitative simulation framework to analyse the potential impacts of the Arctic Sea Route and the Kra Canal on the Europe-Far East seaborne trades, concluding the Kra Canal has significant potential business benefits for companies, but that Arctic routes would not.

Similar work has also been done in relation to other new routes. For example, regarding other canals and alternative potential shipping routes issues, Moryadee et al. (2014) evaluated the potential effects of varying the Panama Canal tolls on the liquefied natural gas (LNG) markets via various scenarios and found expansion will have significant impacts on global trade and businesses. Yip and Mei (2015) adopted a scenario planning method to evaluate the benefits of the then proposed Nicaragua Canal [6] and found it would also significantly impact on world shipping networks. Andersen et al. (2021) explored scheduling problem with uncertain arrival times through the Kiel Canal and found ensuring arrival times was of critical importance.

\section{PESTELE and SWOT analyses}

PESTELE analysis represents the continuing development of what was first introduced by Frances Aguilar in 1964 as ETPS (economic, technological, political and social) analysis, which then came to be known, in a reordered lettering as PEST. Later, other aspects of environmental and legal were added, and the ethical has now also recently been added. Such an analysis has been used in fields ranging from strategic business planning for construction projects (Rastogi and Trivedi, 2016), to planning for renewable energy projects (Zalangera et al., 2014) and international retailing (Nandonde, 2019). The advantages of the PESTELE analysis are that it applies to both specific contexts such as the impact of the Kra Canal on Malaysia (Rahman et al, 2016) and to wider contexts such as sustainable construction (Dalirazar and Sabzi, 2020). It is thus well-suited to considering the impacts of the Kra Canal from a wider perspective.

Comparatively, a SWOT analysis is often used to formulate business strategy and has been applied to fields. For example such as maritime policy (Celik and Kandakoglu, 2012), 
port energy (Christodoulou and Cullinane, 2019), ship safety (Miroslav et al., 2015), trade (Haque et al., 2020) and university education (Dyson, 2004). It is thus suitable for considering the business potential of the Kra Canal.

Notably, these two techniques are often used together, for example, a SWOT/PESTEL analysis has been used for researching the management of water resources (Srdjevic et al., 2012), and elsewhere to consider port energy strategies (Christodoulou and Cullinane, 2019). Thus, the combined use of these methods is ideal to consider the Kra Canal from a maritime business perspective. The PESTELE analysis allows for a consideration of the Kra Canal from a wider contextual perspective, and the SWOT analysis can be targeted more specifically towards business aspects. Throughout these analyses here, we draw on quantitative calculations and qualitative interview data to illustrate points where appropriate and suitable.

\subsection{PESTELE analysis}

Commonly, a PESTELE analysis is presented in a tabular form. Here, this is not done, the reason for not doing so being twofold. First, the overall aim of the PESTELE analysis to consider the Kra Canal in a wider context is a more discursive activity that weighs up a range of factors in an argumentative narrative to reach a conclusion. The second reason is because it is considered that the main piece of information for maritime businesses to know about in relation to the PESTELE analysis of the Kra Canal is the likelihood of its construction, and this is the information that is conveyed in only a few words at the end of the discursive analysis here.

When considering the Kra Canal in terms of political factors, there are a number of aspects and complexities to consider. First, the canal, if constructed, is in Thailand, and previously, it has been the case that internal political uncertainties have led to inaction in building the canal. What is more, the cost of the canal would be immense, and the Thai Government arguably would struggle to justify the amount of tax required politically. This being the case, then it is arguable that the political impetus for building the canal will need to come from a combination of Thailand and another country (e.g. Japan (Sulong, 2012)). Politically, China stands out as the clear candidate to invest in the canal as the canal could greatly help with China's Maritime Silk Route. This was felt to be the case by some of the experts we interviewed, one interviewee from Taiwan commenting that "China also hope to participate the construction of Kra canal. This involves the promotion of One-Belt One-Road policy in China. China hope to obtain better power in shipping via the construction of Kra canal." However, this would require a political agreement between the two countries, and this may require some compromises in terms of ownership, access and profits. There may also be resistance to China's control of the canal from Thailand, as illustrated by the comments of one expert from China we interviewed, who commented that "Last year, I heard one certain party and some people made a stand against for China's participation in Kra canal. Thailand authorities had stopped the investment from the China and denied China to be the main sponsor for this canal." Politically, another consideration is that Thailand is a part of the ASEAN, a group of countries with close ties that includes Singapore and Malaysia. Given that Singapore and Malaysia stand to lose out politically if the Kra Canal is constructed and shipping traffic is diverted, then it is likely these countries will resist the construction of the canal politically. At the current time, therefore, from this wider contextual consideration of political aspects, the likelihood of the canal being constructed appears only slight.

In economic terms, the challenges with the canal appear immense, and partly for the political reasons outlined above. The construction of such a vast project in economic terms will be extremely costly (25-26bn US dollars according to Heng and Yip (2018), and "30 billion US dollars" according to one interviewee from Singapore we spoke to), and Thailand would 
MABR

7,2

168

find it extremely hard to justify the funding of it. For others, also the economic investment required would be huge. Certainly for China it would represent less of an economic challenge to invest in than for Thailand, but it would nevertheless be a significant sum. What is more, in economic terms, the potential loss of income to Singapore and Malaysia means that they will arguably resist the development of the Kra Canal both economically and politically. As one interviewee we spoke to you from Taiwan noted, "I think it might bring some impacts on Singapore, including Malaysia as well." However, this was a complex issue to predict, and one interviewee from Singapore felt the impact on Singapore may not be so significant, saying "Generally, it is believed Singapore will be affected by Kra canal. But I am not sure what the level of impact is. Since the development condition of Kra canal is not good, some people might guess the Singapore's impact is not significant." Safety factors may also have an impact on the canal's ability to maximise shipping transits unless it was constructed to be very wide, one expert from Taiwan noting that "for safety consideration, ship might transit it slowly." Overall, therefore, similarly as with the political aspect above, from an economic perspective at the current time the likelihood of the Kra Canal being constructed appears only slight.

From a social perspective, aspects for consideration relate to income, employment levels, education and also religion. Socially, the canal offers the prospect for both short- to mediumterm employment in constructing the canal, and longer-term employment for people to help service and maintain the canal. This then represents positive social aspects. However, there are some social aspects related to the Kra Canal that are not positive. One aspect will be the fact that the canal will have the psychological and physical effect of cutting off the Buddhist north of Thailand from the Muslim Malay minority in the south. In the decade to 2018, the conflict between the Thai military and Muslim insurgents has left 6,000 dead and 10,000 injured (Er, 2018). Indeed, one expert from Singapore commented that, "The religion between North and South area in Thailand are different. I heard that people in south area would like to be independent in the past. This will bring the emphasis issue for the Thailand authorities when think Kra canal issue." Similarly, one interviewee form Taiwan observed in relation to this issue, a key question is "Can Thailand control the political environment or not?" Here then, from a social perspective, the construction of the canal seems more likely, but there are social issues of potential adverse impact nevertheless.

In technological terms, the construction of the canal is an immense challenge. Many have in the past considered it but not carried it out. For example, Japan expressed an interest in the 1980s but then nothing arose from the intentions, perhaps due to the bursting of the Japanese economic bubble in the late 1980s. Construction of the canal has been estimated to be 10 years (Heny and Yip, 2018), and thus entailing a huge technological challenge. As one interviewee from China noted, "Compared to Suez and Panama canal, constructing Kra canal is more difficult from the perspective of technique." The length has been said by some to be $50 \mathrm{~km}$ (Thongsin, 2002), and by others to be $102 \mathrm{~km}$ (Rahman et al., 2016), and if the canal is to accommodate ultra large crude carriers, it will need to be highly substantial. As one expert from Thailand commented, the "huge money" involved means there would need to be many feasibility and safety studies. Some have proposed a solution to the length of time required may be to use nuclear powered dredges for excavation (Cathcart, 2008), but such dredges would be technically challenging and controversial from ethical and social perspectives. It should also be remembered that the expansion of the Panama Canal took approximately 10 years, and the never constructed Nicaragua Canal also was anticipated to be an immense technological challenge. Technologically, therefore, the challenges involved with building the canal are of a significant scale, and thus make the likelihood of its construction relatively slight.

When considering the canal from an environmental perspective, it is arguable that there are significant positive environmental aspects to the canal being built. In order to quantitatively evaluate the reduction effect of carbon dioxide emission and fuel consumption, this paper takes one 7,000 TEU containership as a comparison. Based on Yuan et al. (2020), the Kra Canal could 
offer a reduction of 722.2 nautical miles $(=1,300 \mathrm{~km})$ for ships when bypassing the Strait of Malacca. Assuming the sailing speed of containership is $20 \mathrm{knots}$, the canal could reduce the sailing time by $36.1(=722.2 / 20)$ hours which is approximate to 1.5 days $(=36.1 / 24)$. Based on Tseng et al. (2021), one containership consumes 72.5 tons per day when sailing the Europe-Asia routes. This containership emits 3.1114 ton carbon dioxide emission when consuming one ton of ship fuel based on normal sailing situation (Tseng and Pilcher, 2016). Thus, it is estimated that using the Kra Canal could reduce $108.75(=1.5 \times 72.5)$ ton fuel and $338.4(=108.75 \times 3.1114)$ ton

carbon dioxide emission when one containership bypasses the Strait of Malacca. Clearly, when multiplied by many containerships using the canal, this represents a huge reduction in emissions that will occur as a result of reduced shipping times is a significant environmental benefit. Nevertheless, it is also the case that the canal will undoubtedly have a hugely negative environmental impact on the area it is constructed on and destroy the natural habitat there. As one expert we interviewed from China observed, there will be both direct and external environmental costs: "direct costs, such as negative damage of ecology, forest, and hill. External costs include air pollution, noise, and health damage for workers and residents around the canal." The proposed Nicaragua Canal was strongly opposed from an environmental perspective (Passary, 2015), and it can be anticipated that there would be similar types of opposition to any construction of the Kra Canal. Yet, many experts interviewed felt that international rules and guidelines would ensure the environmental impact was controlled. For example, in the words of one expert from Taiwan: "Kra canal must follow related environmental rules in the future in order to reduce potential pollutants and protect the land resources, ecological environment, and human living quality." From an environmental perspective, therefore the likelihood of the canal being constructed seems uncertain.

From a legal perspective, there appears to be no reason why the Kra Canal could not be constructed. Clearly, there would need to be legal agreements drafted between the involved parties, and the project would involve the relocation of approximately 65,000 people (Chalermpalanupap, 2021). Nevertheless, legally there appears no major impediment to the building of the canal, and it therefore appears likely from a Legal perspective.

Ethically, the Kra Canal can be said to have positive ethical dimensions in that it will benefit the Thai economy and generate significant income that could be used for projects that would improve living standards and other ethically related aspects. Ethically, it will also mean health benefits for many worldwide through a reduction in emissions and improvement in health conditions as a result. Nevertheless, it will involve the relocation of many individuals from their homes, and this represents significant ethical challenges to the project as does the possibility of it creating unrest due to religious separation of the north and south. Similarly therefore to the environmental perspective, it is arguable that the likelihood of the canal being built is uncertain, although nevertheless a possibility.

In conclusion, therefore, this discursive PESTELE analysis suggests that the likelihood of the Kra Canal being constructed is on the whole relatively low. Although from a legal perspective, the likelihood looks good; from an ethical and environmental perspective, the likelihood is uncertain. Moreover, from political, economic, social and technological perspectives, the likelihood seems very slight. Thus, for any maritime businesses considering planning for the canal's appearance, this current assessment would tend to suggest that this is not necessary. Nevertheless, we continue with a consideration of the SWOT analysis for shipping companies and regional ports as, despite the above PESTELE showing that the canal's construction appears unlikely, it may at some point appear.

\subsection{SWOT analysis}

In contrast to the above approach to presentation of the PESTELE analysis, here the SWOT analysis uses a table to present the information. This is because in this case, it is more suitable 
MABR

7,2

and far clearer to present the information in this format for this analysis. The table presents the analysis for both shipping companies and for hub ports along the Kra Canal route but also for ports that would be adversely affected by the construction of the canal as well. Underneath the table, quantitative and qualitative data are used to illustrate and expand on some of the contents (see Table 1).

From the economic strengths and opportunities perspective, for the Thai Government, the construction cost of Kra Canal will cost an estimated US\$ 28bn (Liang, 2015; Er, 2018). The Kra Canal authority will charge toll fees to recover the construction and maintenance costs, and further earn reasonable profits. However, the level of toll fee depends on the distance reduction when adopting Kra canal. Taking the Panama Canal as a case, the expansion project cost of Panama Canal in 2016 was estimated to be US\$ 5.25bn [7] and only accounts for quarter cost when comparing the Kra Canal (US\$28bn). The reduction distance of Kra Canal and Panama Canal are 750 and 15,000 nautical miles, respectively (Rahman et al., 2016; Herrera et al., 2017). Thus, the distance reduction effect of Kra Canal is significantly lower than the Panama Canal, and shipping companies will need to decide whether the weakness of the level of the toll outweighs the strength of the reduced oil consumption and distance travelled. As one expert we interviewed from China noted, "During the high oil price period, shipping operators might evaluate another routes, including Kra canal."

Also, taking crude oil transport as an example, assuming the sailing cost of the crude ship is 0.00106 US \$ per ton-nautical mile and one ton crude oil is equal to 6.5 barrels, 15 million ton crude oils have been transported by the Strait of Malacca per day (Lin et al., 2018). It is estimated that about $6.69(=15$ million $\times 750 \times 0.00106 / 6.5 \times 365)$ US $\$$ million transport costs can be saved per year (assuming one year is 365 days) if all crude ships are transferred from Strait of Malacca to Kra Canal. From the perspective of shipping economic benefit, sailing costs reduction of crude oil transport (US\$ 6.69m) is limited when comparing the construction cost of Kra Canal (US\$28bn). Further, crude oil companies must pay the toll fee of Kra Canal, and it is possible that crude oil ships may choose the Strait of Malacca, particularly if the toll is considered to be high and the oil price is low.

The issue of the lack of fully developed ports and hinterland around the Kra Canal were also noted by the experts we spoke to. One expert from China commented on how the transit speed and hinterland would need to be developed, saying the Thai Government should "also should think how to effectively develop transit speed and hinterland transport in order to enhance its competitiveness." Further, one expert from Taiwan felt that there needed to be more developed ports on the route and that current ports were not good, saying "Currently,

\begin{tabular}{|c|c|c|c|}
\hline & Shipping companies & Ports on the route & Ports not on the route \\
\hline Strengths & $\begin{array}{l}\text { Reductions in sailing times, fuel costs } \\
\text { and emissions } \\
\text { Reduction in congestion } \\
\text { Safer route with less piracy }\end{array}$ & $\begin{array}{l}\text { Increase in trade } \\
\text { Port hinterland benefits }\end{array}$ & $\begin{array}{l}\text { Established and } \\
\text { developed }\end{array}$ \\
\hline Weaknesses & $\begin{array}{l}\text { Competition with other companies } \\
\text { for space } \\
\text { Not as wide as the Malacca Straits } \\
\text { Need to pay a toll }\end{array}$ & $\begin{array}{l}\text { Competition with others } \\
\text { for trade } \\
\text { Not as developed as } \\
\text { existing ports }\end{array}$ & Now further away \\
\hline Opportunities & $\begin{array}{l}\text { Greater economies of scale } \\
\text { Increase market share } \\
\text { Greater CSR } \\
\text { Growth in company size }\end{array}$ & $\begin{array}{l}\text { Increased income } \\
\text { Economic growth }\end{array}$ & No opportunities \\
\hline Threats & No threats & No threats & Loss of income \\
\hline
\end{tabular}

Table 1. 
the location of Kra canal does not locate at the main shipping routes (trunk). The development resource of ports are not good yet." Such considerations are a key for shipping companies and underline the significant interconnection of aspects such as nearby ports and hinterland development for the success of the Kra Canal. In other words, the Kra Canal's success rests on far more than the Kra Canal alone.

\section{Discussion}

The above PESTELE and SWOT analyses show that the likelihood of the Kra Canal being constructed appears quite low, but if it does reach fruition then the benefits for shipping companies and hub ports are significant. In many ways, analogies can be made between the Kra Canal and other existing canals such as the Suez and Panama canals, and if it is constructed, it will have similar positive effects as these canals have had. It will help reduce shipping times and also the emission of carbon and environmentally hazardous gases. Not only this but today the Kra Canal holds the promise of facilitating the Maritime Silk Road, and thereby aiding China's One Belt One Road Initiative, increasing trade worldwide and benefitting Thailand, Vietnam and shipping companies in many countries around the world.

And yet, it remains unconstructed and it remains to be started. Perhaps, this is because it also has many similarities with another as yet unconstructed canal - the Nicaragua Canal. Although at first sight, the Kra Canal holds much potential and also has many potential environmental benefits in terms of reducing emissions and shipping journeys. However, when considered with the wider context, PESTELE analysis as above, a number of challenges appear. True it has the potential to benefit the ASEAN region, and this is a key strength, but at the same time, it also has the potential to divide and unsettle the region by shifting the balance of economic benefits amongst the individual ASEAN countries and here lies a key political issue. Not only this but whilst it presents economic potential for countries such as China and Thailand, it represents a potential economic loss to countries such as Singapore and Malaysia, for whom the current status quo with trade flowing the Straits of Malacca brings economic benefits.

What is more, it should be considered that the actual qualitative weight of the economic and environmental positives are, when compared with those that were offered by the Panama and Suez canals, relatively slight in terms of the existing status quo. In other words, the cost of constructing and developing the Kra Canal is, at the moment, perhaps simply not worth the potential benefits it could bring. And yet, for shipping companies and hub ports that stand to gain from the opportunities and strengths that the canal offers, it holds nothing but positive potential.

Where then, does this leave the current situation and what does this all mean? We suggest that the above can help inform any strategies adopted by a number of stakeholders. First, for the Thai Government and ASEAN nations; politically, the question remains how to manage the development of the Kra Canal so that negative elements of the PESTELE analysis can be made positive. Second, the SWOT analysis suggests that for shipping companies trading on the AsiaEurope route, they should strategically plan and acquire contractual rights for particular routes in the medium and longer term but only when the canal's construction commences. Furthermore, we hope the analysis can help inform future studies into the viability and complexity of any plans to construct and develop the Kra Canal and to help with improving the shipping efficiency and environmental impact in the region.

\section{Conclusion}

Along with other countries such as Nicaragua, Thailand has long considered the possibility of a canal being constructed across the Kra Isthmus as a possibility to reduce shipping journey times along the Asia-Europe route. Many studies have been conducted regarding the potential benefits to shipping times and hub ports for when the canal becomes active and up and running. 
MABR

7,2

This paper complemented these studies by undertaking a wider context-based PESTELE analysis that considered a range of factors regarding the challenges involved in building the canal, and a shorter and more focused SWOT analysis that considered the potential benefits of the canal for shipping companies and hub ports. These analyses drew on quantitative calculations and qualitative data from semi-structured interviews with experts $(n=20)$ form four countries in the region and were undertaken with the fundamental goal of attempting to consider the feasibility of the canal and its potential impact on maritime business. Further, to consider why it is that the Kra Canal has never been constructed, particularly when compared to other routes such as the Suez and Panama canals that have reached fruition, and to routes such as the Nicaragua canal, which have not. What these analyses suggest is that, despite offering the promise of greater economic and environmental sustainability, particularly for shipping companies, there remain significant political, economic and technological challenges involved with building the canal that make its construction in the near future appear unlikely. It is hoped that what is outlined can help explain why the Kra Canal remains unconstructed but also help inform any serious attempts in the future to facilitate its construction. In addition it is hoped the above can offer important decision information for ASEAN governments, for other governments, and also for shipping companies, port operators and researchers who have interests in the Asia-Europe shipping route and in future planning for the routes they will adopt.

\section{Notes}

1. This canal connects the Gulf of Thailand with the Andaman Sea across southern Thailand (Yuan et al., 2020).

2. Experts' experience ranged from 10 years to 25 years and averaged 19. Interviews averaged $22 \mathrm{~min}$ in length and contained questions such as "Who will benefit from the Kra canal?" and "What will be the financial impact of the canal?" All interviews were conducted in experts' native language for ease of expression (Cortazzi et al., 2011) and all data is anonymous (Christians, 2011).

3. It is estimated that about 70,000-80,000 vessels pass the Straits of Malacca annually (Heng and Yip, 2018).

4. For China's authorities, the Kra Canal might reduce shipping costs of oil transport and minimise the threat of any blockade of the Strait of Malacca.

5. The Association of South East Asian Nations includes Brunei Darussalam, Myanmar/Burma, Cambodia, Indonesia, Laos, Malaysia, Philippines, Singapore, Thailand, Vietnam.

6. The Nicaragua canal is currently abandoned, possibly due to the immense challenges and adverse environmental impacts it was faced with (see Chen et al., 2019).

7. https://en.wikipedia.org/wiki/Panama_Canal

\section{References}

Aksenov, Y., Popova, E.E., Yool, E., Nurser, A.J.G., Williams, T.D., Bertino, L. and Bergh, J. (2018), “On the future navigability of Arctic sea routes: high-resolution projections of the Arctic Ocean and sea ice”, Marine Policy, Vol. 75, pp. 300-317.

Andersen, T., Hove, J.H., Fagerholt, K. and Miesel, F. (2021), "Scheduling ships with uncertain arrival times through the Kiel Canal", Maritime Transport Research, Vol. 2 No. 100008, pp. 1-17, doi: 10.1016/j.martra.2020.100008.

Billington, M. (2011), "Kra Canal, one of LaRouche's great projects' is back on the agenda”, Executive Intelligence Review, Vol. 38 No. 34, pp. 17-19.

Cathcart, R.B. (2008), "Kra Canal (Thailand) excavation by nuclear-powered dredges", International Journal of Global Environmental Issues, Vol. 8 No. 3, pp. 248-255, doi: 10.1504/IJGENVI.2008.018639.

Celik, M. and Kandakoglu, A. (2012), "Maritime policy development against ship flagging out dilemma using a fuzzy quantified SWOT analysis", Maritime Policy and Management, Vol. 39 No. 4, pp. 401-421. 
Chalermpalanupap, T. (2021), Canals and Land Bridges: Mega-Infrastructure Proposals for Southern Thailand, ISEAS - Yusof Ishak Institute, Singapore.

Chen, J., Notteboom, T., Liu, X., Yu, H. and Nikitakos, N. (2019), "The Nicaragua Canal: potential impact on international shipping and its attendant challenges", Maritime Economics and Logistics, Vol. 12 No. 1, pp. 79-98.

Christians, C.G. (2011), "Ethics and politics in qualitative research", in Denzin, N.K. and Lincoln, Y.S. (Eds), The Sage Handbook of Qualitative Research, Sage, Thousand Oaks, CA, pp. 61-80.

Christodoulou, A. and Cullinane, K. (2019), "Identifying the main opportunities and challenges from Kra Canal the implementation of a port energy management system: a SWOT/PESTLE Analysis", Sustainability, Vol. 11 No. 21, 6046.

Cortazzi, M., Pilcher, N. and Jin, L. (2011), "Language choices and 'blind shadows': investigating interviews with Chinese participants", Qualitative Research, Vol. 11 No. 5, pp. 505-535.

Dalirazar, S. and Sabzi, Z. (2020), "Strategic analysis of barriers and solutions to development of sustainable buildings using PESTLE technique", International Journal of Construction Management, pp. 1-15, doi: 10.1080/15623599.2020.1854931.

Dyson, R.G. (2004), "Strategic development and SWOT analysis at the university of Warwick", European Journal of Operational Research, Vol. 152 No. 3, pp. 631-640.

Er, L.P. (2018), “Thailand's Kra Canal proposal and China's maritime silk road: between fantasy and reality?”, Asian Affairs: An American Review, Vol. 45 No. 1, pp. 1-17.

Haque, H.M.E., Dhakal, S. and Mostafa, S.M.G. (2020), "An assessment of opportunities and challenges for cross-border electricity trade for Bangladesh using SWOT-AHP approach”, Energy Policy, Vol. 137, 111118, doi: 10.1016/j.enpol.2019.111118.

Heng, Z. and Yip, T.L. (2018), "Impacts of Kra Canal and its toll structures on tanker traffic", Maritime Policy and Management, Vol. 45 No. 1, pp. 125-139.

Herrera, M., Agrell, P.J., Manrique-de-Lara-Peñate, C. and Trujillo, L. (2017), "Vessel capacity restrictions in the fleet deployment problem: an application to the Panama Canal", Annals of Operations Research, Vol. 253, pp. 845-869.

Lam, P.E. (2018), "Thailand's Kra Canal proposal and China's maritime silk road: between fantasy and reality?", Asian Affairs: An American Review, Vol. 45, pp. 1-17.

Lau, C.Y. and Lee, J.W.C. (2016), “The Kra Isthmus Canal: a new strategic solution for China's energy consumption scenario?", Environmental Management, Vol. 57, pp. 1-20.

Liang, L.H. (2015), "Thailand, China sign agreement to construct a new strategic Kra Canal”, Seatrade Maritime News, available at: https://www.seatrade-maritime.com/asia/thailand-china-signagreement-construct-new-strategic-kra-canal.

Lin, D.Y. and Huang, K.L. (2018), "An equilibrium-based network model for international container flows", Maritime Policy and Management, Vol. 44 No. 8, pp. 1034-1055.

Lin, D.Y., Chen, C.Y., Yuan, Y.W., Chen, J.L., Hsu, N.Y. and Lee, Y. (2018), A Study on the Enhancement of the Global Container Shipping Network Model, Institution of Transportation, Taipei.

Maritime Executive (2020), "Thailand takes a step back from Kra Canal proposal", available at: https://www.maritime-executive.com/article/thailand-takes-a-step-back-from-kra-canal-proposal (accessed January 2021).

Meng, Q., Zhang, Y. and Xu, M. (2017), "Viability of transarctic shipping routes: a literature review from the navigational and commercial perspectives”, Maritime Policy and Management, Vol. 44 No. 1, pp. 16-41.

Min, C.H. (2015), "Renewed hype over China-Thai canal project: 5 things about the Kra Canal", The Straits Times, Singapore Press Holding, Tao Payoh N, Singapore.

Miroslav, R., Dario, M. and Darko, M. (2015), "SWOT analysis of deficiencies on ship components identified by port state control inspections with the aim to improve the safety of maritime navigation”, Engineering, Vol. 66 No. 3, pp. 61-73. 
MABR

7,2

Moryadee, S., Gabriel, S.A. and Rehulka, F. (2014), "The influence of the Panama Canal on global gas trade", Journal of Natural Gas Science and Engineering, Vol. 20 No. 11, pp. 161-174.

Mulligan, R.F. and Lombardo, G.A. (2011), "Panama Canal expansion: alleviating global climate change", WMU Journal of Marine Affairs, Vol. 10, pp. 97-116.

Nandonde, F.A. (2019), "A PESTLE analysis of international retailing in the East African Community”, Global Business and Organizational Excellence, Vol. 38 No. 4, pp. 54-61.

Passary, S. (2015), "Scientists wary about environmental effects of canal-building project in Nicaragua", Tech Times, available at: https://www.techtimes.com/articles/37433/20150305/ scientists-wary-about-environmental-effects-of-canal-building-project-in-nicaragua.htm (accessed February 2021).

Rahman, N.S.F.A., Salleh, N.H.M.S., Najib, A.F.A. and Lun, V.Y.H. (2016), "A descriptive method for analyzing the Kra Canal decision on maritime business patterns in Malaysia", Journal of Shipping and Trade, Vol. 1 No. 13, pp. 1-16.

Rastogi, N and Trivedi, M.K. (2016), "PESTLE technique-a tool to identify external risks in construction projects", International Research Journal of Engineering and Technology, Vol. 3 No. 1, pp. 384-388.

Srdjevic, Z., Bajcetic, R. and Srdjevic, B. (2012), "Identifying the criteria set for multicriteria decision making based on SWOT/PESTLE analysis: a case study of reconstructing a water intake structure", Water Resources Management, Vol. 26 No. 12, pp. 3379-3393.

Sulong, R.S. (2012), "The Kra Canal and Southeast Asian relations", Journal of Current Southeast Asian Affairs, Vol. 31 No. 4, pp. 109-125.

Thongsin, A. (2002), The Kra Canal and Thai Security, Dissertation, The Naval Postgraduate School, Monterey.

Tseng, P.H., Zhou, A. and Huang, F.J. (2021), "Northeast Passage in Asia-Europe liner shipping: an economic and environmental assessment", International Journal of Sustainable Transportation, Vol. 15 No. 4, pp. 273-284.

Tseng, P.H. and Pilcher, N. (2016), "Exploring the viability of an emission tax policy for ships at berth in Taiwanese ports", International Journal of Shipping and Transport Logistics, Vol. 8 No. 6, pp. 705-722.

Yip, T.L. and Mei, C.W. (2015), "The Nicaragua Canal: scenarios of its future roles”, Journal of Transport Geography, Vol. 43, pp. 1-13.

Yuan, C.Y., Hsieh, C.H. and Su, D.T. (2020), "Effects of new shipping routes on the operational resilience of container lines: potential impacts of the Arctic Sea Route and the Kra Canal on the Europe-Far East seaborne trades", Maritime Economics and Logistics, Vol. 22, pp. 308-325.

Zalengera, C., Blanchard, R.E., Eames, P.C., Juma, A.M., Chitawo, M.L. and Gondwe, K.T. (2014), "Overview of the Malawi energy situation and A PESTLE analysis for sustainable development of renewable energy", Renewable and Sustainable Energy Reviews, Vol. 38, pp. 335-347.

Zeng, Q., Wang, G.W.Y., Qu, C. and Li, K.X. (2018), "Impact of the Carat Canal on the evolution of hub ports under China's Belt and Road initiative", Transportation Research Part E, Vol. 117, pp. 96-107.

\section{Corresponding author}

Nick Pilcher can be contacted at: N.Pilcher@napier.ac.uk

For instructions on how to order reprints of this article, please visit our website:

www.emeraldgrouppublishing.com/licensing/reprints.htm

Or contact us for further details: permissions@emeraldinsight.com 